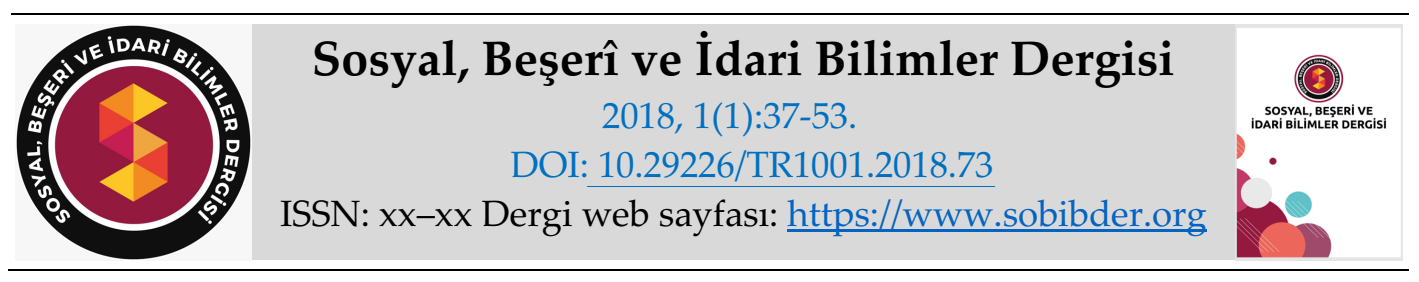

ARASTTIRMA MAKALESI

\title{
Psikolojik Şiddetin İş Doyumu Üzerindeki Etkisi
}

Esin ŞAKACI, Gazi Üniversitesi, Sosyal Bilimler Enstitüsü, İnsan Kaynakları Yönetimi Anabilim Dall, Ankara, e-posta: esinsakacii@gmail.com

ORCID: https://orcid.org/0000-0003-2220-4189

Öz

Araştırmada tüm dünyada örgütler için önemli bir sorun olan psikolojik şiddetin (mobbing), çalışanların verimliliğini etkileyen iş doyumu üzerindeki etkisinin ne düzeyde olduğu ortaya çıkarılmaya çalışılmıştır. Araştırma Ankara'da bulunan özel ve kamu kurumlarında çalışan bireyler üzerinde uygulanarak psikolojik şiddet mağduru olan çalışanların maruz kaldıkları yıldırma ile demografik özellikleri ve iş doyumları arasındaki ilişki 515 kişiye uygulanan anket sorularına verilen cevaplardan elde edilen verilerle analiz edilerek saptanmaya çalışılmıştır. Araştırmanın sonucunda psikolojik şiddet ile iş doyumu arasında anlamlı bir ilişkinin olduğu, psikolojik şiddete maruz kalındığı ölçüde çalışanların iş doyum düzeylerinin azaldığı dolayısıyla da verimliliklerinin azaldığı görülmektedir.

Anahtar Kelimeler: Psikolojik Taciz, Psikolojik Şiddet, İşyerinde Yıldırma, İş Doyumu, İş Tatmini.

Makale Gönderme Tarihi: 11.10 .2018

Makale Kabul Tarihi: 15.12.2018

\section{Önerilen Atıf:}

Şakacı, E. (2018). Psikolojik Şiddetin İş Doyumu Üzerindeki Etkisi, Sosyal, Beşeri ve İdari Bilimler Dergisi, 1(1):37-53.

(C) 2018 Sosyal, Beşerî ve İdari Bilimler Dergisi. 


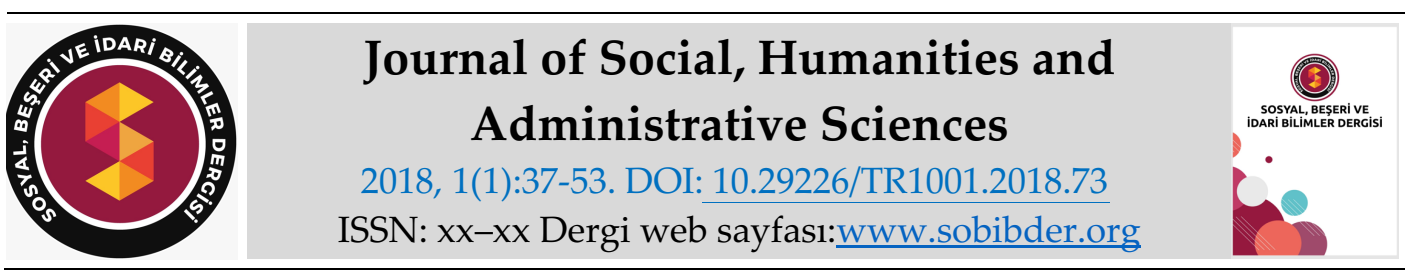

$\underline{\text { RESEARCH PAPER }}$

\title{
The Effect of Psychological Violence on Job Satisfaction
}

Esin ŞAKACI, Gazi University, Graduate School of Social Sciences, Department of Human Resources Management, Ankara, e-mail: esinsakacii@gmail.com

ORCID: https://orcid.org/0000-0003-2220-4189

\begin{abstract}
In this study, the aim was to find out psychological violence (mobbing), and the level of the effect on job satisfaction, which affects employees' productivity. which is an important problem for organizations all over the world. The research has been carried out on individuals working in private and public institutions in Ankara and tried to determine the relationship between the intimidation, demographic characteristics and job satisfaction of employees who suffered psychological violence victims by analyzing the data obtained from the answers given to the questionnaire of 515 individuals. As a result of the research, it is seen that there is a meaningful relationship between psychological violence and job satisfaction, and the level of job satisfaction of the workers exposed to psychological violence decreases and therefore their productivity decreases.
\end{abstract}

Keywords: Psychological Abuse, Mobbing, Psychological Violence, Job Satisfaction.

Received: 11.10 .2018

Accepted: 15.12.2018

\section{Suggested Citation:}

Şakaci, E. (2018). The Effect of Psychological Violence on Job Satisfaction, Journal of Social, Humanities and Administrative Sciences, 1(1):37-53.

(c) 2018 Sosyal, Beşerî ve İdari Bilimler Dergisi. 


\section{GİRiş}

Çalışanlar, bir örgütün temel üretim faktörüdür. Bir örgütün başarı veya başarısızlığını belirleyen en önemli faktör, o örgütte çalışanların sayısı ve niteliğidir. Bazı örgütlerin diğerlerinden daha güçlü ve hızlı biçimde büyümelerinin ve gelişmelerinin temel sebebi de sahip olunan parasal sermayeden çok, uygun sayı ve kapasitede çalışanların bulunması ve bunun sağladığı üstünlüktür (Barutçugil, 1992:76).

Artan rekabet, sürekli değişen teknolojik ve ekonomik koşullar örgütlerin başarılı olmak için daha hızlı, daha esnek, daha girişimci ve daha yenilikçi olmasını gerektirmektedir. Günümüz değişim ve rekabet ortamında örgütler için yaşamsal öneme sahip olan bu gereklilikleri yerine getirmenin yolu ise çalışanların yaratııılıklarını ve gelişimlerini destekleyen bir örgüt ortamı yapilandırmaktır.

Örgütlerde çalışanların elde etmek istedikleri çıkarların sınırlı olması çalışanlar arasında çatışmalara ve mobbing adı verilen psikolojik şiddet ve yıldırmaların yaşanmasına neden olmaktadır. İngilizce' de 'mob' sözcüğü isim olarak kalabalık, çete, güruh, izdiham gibi anlamlara gelirken; fiil olarak bir yerde toplanmak, saldırmak, rahatsız etmek, çevresini sarmak, kuşatmak anlamlarında kullanılmaktadır. Mob kelimesinden türetilen "mobbed" sözcügü sosyolojide aşırı kalabalıkları ifade etmek için kullanılırken aynı sözcükten türetilen "mobbing" terimi, bazı hayvan türlerinin kendi aralarına davetsiz katılan diğer bir hayvan veya hayvanlara karşı birlikte hareket ederek taciz etmelerini ifade etmede kullanılır. Bu kapsamda "Mobbing" terimi ile ifade etmek istenen husus öfkeli ve kızgın kalabalığın bir başkasına karşı topluca saldırıya geçmesi durumudur (Gün, 2010:15)

Psikolojik şiddet üzerine araştırma yapanlar, mobbing olgusunu bir tek sözcükle ifade etmek yerine kavramı; 'duygusal taciz', 'psikolojik terör' ve çalışanı işyerinde 'yıldırma'ya yönelik her tür psikolojik saldırı anlamında çeşitli kavramlar kullanmaktadırlar (Einarsen, 1999:15) Psikolojik yıldırma, bir grubun yaptığı psikolojik bir saldırıdır. Çalışanlara üstleri, astları veya eşit düzeyde olanlar tarafından sistematik bir biçimde uygulanan her tür kötü muamele, şiddet, tehdit, aşağılama gibi anlamlara gelmektedir. Şiddet, hedef seçilen kişiye ahlak dışı ve düşmanca bir biçimde uygulanır. Bunun sonucunda kişi, örgüt içinde savunmasız kalır ve yardım alamaz.

Bir örgütte psikolojik şiddetten söz edebilmek için, kasıtlı bir biçimde sürekli ve sistematik bir biçimde yıldırma taktiği kullanılması ve buna maruz kalan kişinin karşılaştığı olumsuz davranışlardan kendini koruyamayacak duruma gelmiş olması gerekmektedir (Leymann, 1996:251). Yaşanan bu yıldırmalar bazen açık bir şekilde bazen ise örtülü bir biçimde kendini göstermektedir. Çalışanın stres, kırgınlık, dışlanmışlık, güvensizlik ve tedirginlik hissetmesi gibi sonuçlara neden olarak (Şahin vd., 2006:554) motivasyonun düşmesine sebep olan aynı zamanda da örgütlerin amaçlarına ve hedeflerine ulaşmasını zorlaştıran ya da çeşitli şekillerde örgüte maliyet olarak yansıyan bu çatışmaların kontrol edilmesi, kaldırılması ya da faydaya çevrilerek yönetilmesi son derece önemli olmaktadır.

Psikolojik şiddet algısının sonucunda bireyin iş ve işyerine karşı tutumunu yani iş doyumunu ciddi derecede etkilediği anlaşılmaktadır. İş doyumu kişinin işindeki performansını belirleyen en önemli unsurdur. İş doyumu, "işten elde edilen maddi çıkarlar ve çalışanın beraber çalışmaktan zevk aldığı iş arkadaşları ile bir eser meydana getirmesinin sağladığı mutluluk" şeklinde tanımlanabilir (Şimşek, Çelik ve Akgemci 2016:164). Çalışan, oluşturduğu bir eseri somut olarak görebiliyorsa bu kendisi için bir gurur kaynağı olacaktır ve bu durumdan memnun olacaktır. Eğer kişi işinden memnunsa işini seviyor ve işi hakkında olumlu düşüncelere sahip demektir. Bu da iş performansını yükseltmektedir (Ellis ve Dick, 2003).

İş, bireylerin ekonomik, sosyal ve psikolojik boyutlardaki çeşitli ihtiyaçlarını karşılamaları için imkan yaratarak yaşamlarında önemli bir rol oynamaktadır (Sarabahksh vd., 1989:239). 
Ekonomik anlamda iş, bireyin yaşamını sürdürmek ya da belirli bir düzeye yükseltmek amacıyla giriştiği bedensel ve düşünsel çabadır (Sabuncuoğlu, 1997:15). Sosyal anlamda iş, çalışma yaşamında başkalarıyla iletişim kurarak onlarla birlikte yaşamlarını devam ettirme çabasıdır. Psikolojik anlamda ise iş, çalışana saygınlık ve doyum sağlayan bir olgudur (Sabuncuoğlu ve Tokol, 2001:4). Çalışma ile birey sadece maddi kazanımlar elde ederken, aynı zamanda da işinden mutluluk duyması, başarı kazanması, tanınması, takdir görmesi, kendini ispatlaması ve doyum sağlaması gibi psikolojik kazanımlar da elde etmektedir (Kalleberg ve Loscocco, 1983:78).

Bir işe sahip olmanın, üretebilmenin verdiği gurur, elde edilen başarının yarattığı duygu, işini sevme ve anlamlı bir eylemde bulunma gibi çeşitli psikolojik fonksiyonlar, iş doyumunun insan hayatında önemli bir yere sahip olduğunu göstermektedir (Acar, 2007:2).

İşgören, işinden ve iş ortamından beklentilerinin yeterince karşılanmadığı 1 algısına sahip olduğu takdirde, iş tatminsizliği ortaya çıkmaktadır. İş tatminsizliği, işgörenin işgücü verimliliğinin olumsuz etkilenmesine, işe bağlılığının azalmasına ve isteğe bağlı işgücü devir hızının artmasına neden olmaktadır. Aynı zamanda işgörenin sağlık durumu da olumsuz etkilenmektedir. İş tatmini düşük işgörenlerde sinirsel (uykusuzluk, baş ağrisı vb.) ve duygusal çöküntülerin (stres, hayal kırıklığı vb.) oluştuğu ve iş tatminsizliği ile aralarında anlamlı bir ilişki olduğu saptanmıştır (Akıncı, 2002:4).

Bu çalışmada da, hem çalışanları etkileyen hem de örgütün işleyişini etkileyen gittikçe artan bir öneme sahip olan psikolojik şiddet kavramının çalışma hayatındaki önemi ve psikolojik şiddet olgusunun çalışanların iş doyumu ile ilişkisi araştırılmaya çalışılmıştır. Psikolojik şiddet ile iş doyumu arasındaki ilişki araştırmanın ana problemini oluşturmaktadır. Örgütlerde çalışanların verimliğini etkileyerek çalışma ortamındaki birçok soruna yol açabilen psikolojik şiddet algısı incelenerek çalışanların iş doyum düzeylerini nasıl etkilediği ortaya konulacaktır. Ayrıca, çalışılan sektör, cinsiyet değişkeni, yaş değişkeni, hizmet süresi, eğitim durumu, medeni durumu ve yöneticilik görevi değişkenleri açısından karşılaştırmalı bir araştırma yapılacaktır.

\section{Araştırmanın amacına dayanarak aşağıdaki hipotezler test edilecektir:}

H1: Psikolojik şiddet ile iş doyumu arasında ilişki vardır

H2.1: Araştırmaya katılan çalışanların psikolojik şiddete algıları yaş dağılımına göre farklılık göstermektedir.

H2.2: Araştırmaya katılan çalışanların iş doyum düzeyi yaş dağılımına göre farklılık göstermektedir.

H3.1:Araştırmaya katılan çalışanların psikolojik şiddete algıları eğitim düzeyine göre farklılık göstermektedir.

H3.2: Araştırmaya katılan çalışanların iş doyum düzeyi eğitim düzeyine göre farklılık göstermektedir.

H4.1 : Araştırmaya katılan çalışanların psikolojik şiddete algıları kıdem süresine göre farklılık göstermektedir

H4.2: Araştırmaya katılan çalışanların iş doyum düzeyi kıdem süresine göre farklılık göstermektedir.

H5.1: Araştırmaya katılan çalışanların psikolojik şiddete algıları cinsiyet dağılımına göre farkl1l1k göstermektedir

H5.2: Araştırmaya katılan çalışanların iş doyum düzeyi cinsiyet dağılımına göre farklılık göstermektedir. 
H6.1: Araştırmaya katılan çalışanların psikolojik şiddete algıları medeni durumuna göre farklılık göstermektedir

H6.2: Araştırmaya katılan çalışanların iş doyum düzeyi medeni durumuna göre farklılık göstermektedir.

H7.1: Araştırmaya katılan çalışanların psikolojik şiddete algıları çalışılan kuruma göre farklılık göstermektedir

H7.2: Araştırmaya katılan çalışanların iş doyum düzeyi çalışılan kuruma göre farklılık göstermektedir.

H8.1: Araştırmaya katılan çalışanların psikolojik şiddete algıları yönetici olup olmamasına göre farklılık göstermektedir

H8.2: Araştırmaya katılan çalışanların iş doyum düzeyi yönetici olup olmamasına göre farklılık göstermektedir.

\section{YÖNTEM}

Bu araştırma Ankara'da kamu ve özel sektör çalışanları üzerinde gerçekleştirilmiştir. Ayrıca, belirlenen demografik özelliklerin belirtilen bağımlı değişken üzerindeki etkilerini ölçmekte çalışmanın amacı kapsamındadır.

\section{Örneklem}

Araştırmanın geniş bir alanı kapsaması söz konusu alan ve işletmelerin tümüne ulaşmada bir takım zorlukları gündeme getirmektedir. Bu sebeple, araştırmada belirlenen bu evren üzerinden örneklem alınma yoluna gidilmiştir. Araştırmadan kullanılan Ryan'ın Örneklem sayısının belirlenmesine ilişkin geliştirmiş olduğu formül aşağıdaki şekildedir;

$$
\begin{aligned}
& \mathrm{n}=\frac{\mathrm{NPq}}{\frac{(\mathrm{N}-1) \mathrm{B}^{2}+\mathrm{Pq}}{\mathrm{Z}^{2}}} \\
& n=\frac{29000000(0,5)(0,5)}{\frac{(2900000-1)(0,05)^{2}+(0,5)(0,5)}{(1,96)^{2}}} \\
& \mathrm{n}=387
\end{aligned}
$$

Araştırma evrenini oluşturan Türkiye'deki çalışan sayısı 2018 yılı itibariyle 29 milyondur. (http://www.tuik.gov.tr). Formül evrene uyarlandığında örneklem büyüklügü 387 olarak belirlenmiştir. Evrenden seçilen örneklem grubundan 515 çalışana ulaşılmıştır.

\section{Verilerin Toplanması}

Araştırmada birincil ve ikincil veri kaynaklarından yararlanılmıştır. Araştırmanın kavramsal ve kuramsal kısmında daha önce yapılmış çalışmalar, makaleler, tezler gibi yazılı kaynaklar taranmıştır. Bu çalışmalar ışığında çalışanların maruz kaldıkları psikolojik şiddet ile örgütsel bağlılık arasındaki ilişkiyi saptamaya yönelik anket uygulanmıştır.

Veri toplama aracı üç bölümden oluşmaktadır. Birinci bölümde araştırmaya katılan çalışanların demografik özellikleri, ikinci bölümde çalışanların psikolojik şiddet algı düzeylerini ölçen Heinz Leymann'ın (1993) 45 ifadelik ölçeği ve üçüncü bölümde iş doyumu 
düzeyini ölçen 1967 yılında Weiss, Dawis, England ve Lofquist tarafından geliştiril en kısa formu 20 sorudan oluşan Minnesota iş doyum ölçeğidir.

Psikolojik şiddet algısını ölçmeye yönelik 5'li Likert ölçeği kullanılmıştır. Buna göre ifadeler “Kesinlikle Katılmıyorum(1)", "Katılmıyorum (2)", "Kararsızım (3)", "Katıliyorum (4)", "Kesinlikle Katıllyorum (5)" olarak ölçeklendirilmiştir. Maddelerden ve ölçekten elde edilen düşük puan psikolojik şiddet davranışlarına daha az maruz kalındığını ifade etmektedir. Böylece ölçekte en yüksek puan alan maddeler psikolojik şiddet davranışlarının daha çok olduğu anlamı ortaya çıkmaktadır.

İş doyumunu ölçmeye İş doyumuna ait davranışlara katılım derecelerini belirlemek üzere ise yine 5'liLikert ölçeği kullanılmıştır. Buna göre ifadeler "Hiç Tatmin Edici Değil (1)", "Tatmin Edici Değil (2)”, “Ne Tatmin Edici Ne Değil (3)”, “Tatmin Edici (4)”, “Çok Tatmin Edici (5)” olarak ölçeklendirilmiştir.

\section{Veri Analiz Yöntemi}

$\mathrm{Bu}$ araştırmanın değişkenleri psikolojik şiddet ve iş doyumudur. Her iki değişkeni ölçmek için uygulanan ölçek belirlenen örneklemdeki çalışanlara uygulanmıştır. Uygulama alanındaki bireylerin anketlere verdikleri cevapların geri dönüşümü sağlandıktan sonra veri tabanı oluşturulmuş ve bu veri tabanı SPSS (Statistical Packages for the Social Sciences) programı aracılığıyla bilgisayara yüklenmiştir. Araştırmada elde edilen veriler, araştırmanın amacı doğrultusunda çeşitli istatistikî analizler (frekans, $\mathrm{t}$ testi, One-Way Anova, Pearson Korelasyon) kullanılarak ve konuya ilişkin uzman desteği alınarak yorumlanmıştır.

\section{BULGULAR}

Araştırmanın örneklem grubunu oluşturan çalışanların genel yapısına yönelik tanıtıcı frekans ve yüzde dağılımları Tablo-1 de gösterilmiştir.

Araştırmaya katılanların \%61'i kadın, \%39'u erkektir. Örneklem grubunun çoğunluğu kadınlardan oluşmaktadır. Araştırmaya katılanların yaş aralığı ve frekans dağılımına baktığımızda; çalışanların en yüksek oran ile \%30,0'unun 26-30 yaş aralığında ve en düşük oran ile \%12,0'ının 36-40 yaş aralığında oldukları görülmektedir. Araştırma grubu içerisinde 20-25 yaş aralığındaki çalışanların oranı \%18,1, 31-35 yaş aralığındaki çalışanların oranı \%21,6, 41 ve üzeri yaş aralığındaki çalışanların oranı ise \%18,3 olmaktadır. Araştırmaya katılanların \%27,4'ü kamu sektöründe, \%72,6'sının özel sektörde çalışmaktadır. Örneklem grubundaki çoğunluk özel sektörde çalışmaktadır. Araştırmaya katılanların çalışma yılı yüzde ve frekans dağılımına baktığımızda; \%16,3'ü 0-1 yıl arası, \%35,7'si 2-5 yıl arası, \%19,2'si 6-10 yıl arası, \%10,1'i 11-15 yıl arası, \%18,6'sı 16 yıl ve üzeri çalışmıştır. Araştırmaya katılanların çalışma yılı yüzde ve frekans dağılımına baktığımızda; \%1,7'si ilköğretim, \%7,2'si lise, \%9,1'i önlisans, $\% 55,5^{\prime}$ i lisans, \%26,4'ü lisansüstü eğitim tamamlamıştır. Araştırmaya katılanların \%49,3^ü evli, \%50,7'si bekardır. Örneklem grubunun çoğunluğu bekarlardan oluşmaktadır ancak yüzdelik dağılımdaki fark çok azdır. Araştırmaya katılanların \%33,8'inin yöneticilik vasfı bulunmakta, \%66,2'sının yöneticilik vasfı bulunmamaktadır. 
Tablo 1: Araştırmaya Katılan Çalışanların Cinsiyet, Yaş, Sektör, Kıdem, Eğitim Durumu, Medeni Durum, Yöneticilik Görevi Dağılımı

\begin{tabular}{|c|c|c|}
\hline Cinsiyet & $\mathbf{N}$ & $\%$ \\
\hline Kadın & 314 & 61 \\
\hline Erkek & 201 & 39 \\
\hline Total & 515 & 100 \\
\hline Yaş & $\mathbf{N}$ & $\%$ \\
\hline $20-25$ yaş aralığ & 93 & 18,1 \\
\hline $26-30$ yaş aralığ 1 & 155 & 30,1 \\
\hline 31-35 yaş aralığ 1 & 111 & 21,6 \\
\hline 36-40 yaş aralığ1 & 62 & 12 \\
\hline 41 ve üzeri yaş aralığ1 & 94 & 18,3 \\
\hline Total & 515 & 100 \\
\hline Sektör & $\mathbf{N}$ & $\%$ \\
\hline Kamu çalışanı & 141 & 27,4 \\
\hline Özel sektör çalışanı & 374 & 72,6 \\
\hline Total & 515 & 100 \\
\hline K1dem & $\mathbf{N}$ & $\%$ \\
\hline $0-1$ yıl arası & 84 & 16,3 \\
\hline $2-5$ yıl arası & 184 & 35,7 \\
\hline 6-10 yıl arası & 99 & 19,2 \\
\hline $11-15$ yıl arası & 52 & 10,1 \\
\hline 16 yıl ve üzeri arası & 96 & 18,6 \\
\hline Total & 515 & 100 \\
\hline Eğitim Durumu & $\mathbf{N}$ & $\%$ \\
\hline İlköğretim & 9 & 1,7 \\
\hline Lise & 37 & 7,2 \\
\hline Önlisans & 47 & 9,1 \\
\hline Lisans & 286 & 55,5 \\
\hline Lisansüstü & 136 & 26,4 \\
\hline Total & 515 & 100 \\
\hline Medeni Durum & $\mathbf{N}$ & $\%$ \\
\hline Evli & 254 & 49,3 \\
\hline Bekar & 261 & 50,7 \\
\hline Total & 515 & 100 \\
\hline Yöneticilik Görevi & $\mathbf{N}$ & $\%$ \\
\hline Evet var & 174 & 33,8 \\
\hline Hayır yok & 341 & 66,2 \\
\hline Total & 515 & 100 \\
\hline
\end{tabular}


Tablo 2: Psikolojik Şiddet Boyutları ile İş Doyumu Arasındaki Korelâsyon

\begin{tabular}{|c|c|c|c|c|c|c|c|c|}
\hline & & $\begin{array}{l}\text { Birinci } \\
\text { Boyut }\end{array}$ & $\begin{array}{l}\text { İkinci } \\
\text { Boyut }\end{array}$ & $\begin{array}{l}\text { Üçüncü } \\
\text { Boyut }\end{array}$ & $\begin{array}{l}\text { Dördüncü } \\
\text { Boyut }\end{array}$ & $\begin{array}{l}\text { Beşinci } \\
\text { Boyut }\end{array}$ & $\begin{array}{l}\text { Psikolojik } \\
\text { Şiddet } \\
\text { Ortalaması } \\
\end{array}$ & $\begin{array}{l}\text { İş Doyumu } \\
\text { Ortalaması }\end{array}$ \\
\hline \multicolumn{9}{|l|}{ Boyut-1 } \\
\hline $\begin{array}{l}\text { Mağdurun } \\
\text { Kendini }\end{array}$ & $\mathrm{r}$ & 1 & 0,701 & 0,783 & 0,72 & 0,603 & 0,89 & $-0,572$ \\
\hline $\begin{array}{l}\text { Göstermesine } \\
\text { ve İletişim }\end{array}$ & $\mathrm{P}$ & 0 & 0 & 0 & 0 & 0 & 0 & 0 \\
\hline $\begin{array}{l}\text { Oluşumuna } \\
\text { Saldırılar }\end{array}$ & $\mathrm{N}$ & 515 & 515 & 515 & 515 & 515 & 515 & 515 \\
\hline Boyut-2 & $\mathrm{r}$ & 0,701 & 1 & 0,788 & 0,706 & 0,635 & 0,847 & $-0,484$ \\
\hline $\begin{array}{l}\text { Sosyal } \\
\text { İlişkilere }\end{array}$ & $\mathrm{P}$ & 0 & 0 & 0 & 0 & 0 & 0 & 0 \\
\hline Saldırılar & $\mathrm{N}$ & 515 & 515 & 515 & 515 & 515 & 515 & 515 \\
\hline \multirow{3}{*}{$\begin{array}{l}\text { Boyut-3 } \\
\text { İtibara } \\
\text { Saldırılar }\end{array}$} & $\mathrm{r}$ & 0,783 & 0,788 & 1 & 0,791 & 0,727 & 0,953 & $-0,53$ \\
\hline & $\mathrm{P}$ & 0 & 0 & 0 & 0 & 0 & 0 & 0 \\
\hline & $\mathrm{N}$ & 515 & 515 & 515 & 515 & 515 & 515 & 515 \\
\hline \multicolumn{9}{|l|}{ Boyut-4 } \\
\hline $\begin{array}{l}\text { Yaşam } \\
\text { Kalitesi ve }\end{array}$ & $r$ & 0,72 & 0,706 & 0,791 & 1 & 0,675 & 0,889 & $-0,577$ \\
\hline $\begin{array}{l}\text { Mesleki } \\
\text { Duruma }\end{array}$ & $\mathrm{P}$ & 0 & 0 & 0 & 0 & 0 & 0 & 0 \\
\hline Saldırılar & $\mathrm{N}$ & 515 & 515 & 515 & 515 & 515 & 515 & 515 \\
\hline Boyut-5 & $\mathrm{r}$ & 0,603 & 0,635 & 0,727 & 0,675 & 1 & 0,779 & $-0,368$ \\
\hline $\begin{array}{l}\text { Kişilerin } \\
\text { Sağlığına }\end{array}$ & $\mathrm{P}$ & 0 & 0 & 0 & 0 & 0 & 0 & 0 \\
\hline $\begin{array}{l}\text { Doğrudan } \\
\text { Saldırılar }\end{array}$ & $\mathrm{N}$ & 515 & 515 & 515 & 515 & 515 & 515 & 515 \\
\hline
\end{tabular}

Araştırmaya katılan örneklem grubunun psikolojik şiddet algıları ile iş doyum düzeyi arasındaki ilişki Tablo-2'de gösterilmiştir. Buna göre $r=-0,592$ oranında ters yönde, $p=0,00$ anlamlılık düzeyinde bir ilişki bulunmaktadır. Buna göre $\mathrm{H}_{1}$ hipotezi yeterli kanıtla desteklenmektedir.

Psikolojik şiddet boyutları ile iş doyum düzeyi arasındaki ilişki tek tek incelendiğinde aşağıdaki sonuçlar ortaya çıkmıştır.

- Psikolojik şiddetin ilk boyutu olan "Mağdurun Kendini Göstermesine ve İletişim Oluşumuna Saldırılar" ile iş doyum düzeyi arasında $r=-0,572$ şiddetinde, $\mathrm{p}=0,00$ anlamlılık düzeyinde bir ilişkinin olduğu görülmektedir. 
- Psikolojik şiddetin ikinci boyutu olan "Sosyal İlişkilere Saldırılar" boyutu ile iş doyum düzeyi arasında $\mathrm{r}=-0,484$ şiddetinde, $\mathrm{p}=0,00$ anlamlılık düzeyinde bir ilişkinin olduğu görülmektedir

- Psikolojik şiddetin üçüncü boyutu olan "İtibara Saldırılar"boyutu ile iş doyum düzeyi arasında $r=-0,53$ şiddetinde, $p=0,00$ anlamlılık düzeyinde bir ilişki olduğu görülmektedir.

- Psikolojik şiddetin dördüncü boyutu olan "Yaşam Kalitesi ve Mesleki Duruma Saldırılar" boyutu ile iş doyum düzeyi arasında $r=-0,577$ şiddetinde, $p=0,00$ anlamlılık düzeyinde bir ilişkinin olduğu görülmektedir

- Psikolojik şiddetin beşinci boyutu olan "Kişilerin Sağllğına Doğrudan Saldırılar" boyutu ile iş doyum düzeyi arasında $\mathrm{r}=-0,368$ şiddetinde, $\mathrm{p}=0,00$ anlamlılık düzeyinde bir ilişki olduğu görülmektedir.

Verilerine baktığımızda psikolojik şiddet algısı arttıkça iş doyumu düzeyinin düştüğü anlaşılmaktadır yani psikolojik şiddet algısı düştükçe iş doyumu düzeyi de yükselecektir. İş doyumu düzeyini en çok etkileyen psikolojik şiddet davranışı dördüncü yaşam kalitesi ve mesleki duruma saldırılar olduğu görülmektedir. Çalışana özgüvenini yitirici niteliklerinin altında anlamsız işler verilmesi, maddi ve manevi anlamda yük getirici işler verildiğinde çalışan işine karşı tatminsizlik oluşacak ve çalışmayı istemeyecek duruma gelecektir. Çalışan kendini verimli hissettiği sürece tatmin olacaktır.

Karcıoğlu ve Akbaş (2010;156) çalışmalarında elde ettikleri bulgulara göre; genel olarak psikolojik şiddet ve iş tatmini arasında olumsuz yönde bir ilişki bulunmaktadır. Yani, psikolojik şiddet ve iş tatmini arasındaki ilişki değeri $(\mathrm{r}=-0.490)$ olarak bulunmuş ve çalışanların psikolojik şiddete maruz kalmaları durumunda iş doyumlarının azaldığı gözlenmiştir.

Tablo 3: Çalışanların Psikolojik Şiddete Maruz Kalma Algılarının Yaş Değişkenine Göre Farklılaşması

\begin{tabular}{ccccccc}
\hline & Yaş & $\mathbf{N}$ & $\overline{\mathbf{x}}$ & $\mathbf{s}$ & $\mathbf{F}$ & $\mathbf{P}$ \\
\hline & $20-25$ & 93 & 2,0091 & 0,69298 & & \\
\cline { 2 - 5 } $\begin{array}{c}\text { Psikolojik } \\
\text { Şiddet } \\
\text { Ortalamas1 }\end{array}$ & $26-30$ & 155 & 2,1238 & 0,74022 & & \\
\cline { 2 - 5 } & $31-35$ & 111 & 2,1938 & 0,80598 & & \\
\cline { 2 - 5 } & $36-40$ & 62 & 2,2846 & 0,96283 & & \multirow{2}{*}{0,222} \\
\cline { 2 - 5 } & 41 ve üzeri & 94 & 2,2128 & 0,85685 & & \\
\cline { 2 - 5 } & Total & $\mathbf{5 1 5}$ & $\mathbf{2 , 1 5 3 8}$ & $\mathbf{0 , 7 9 9 4 4}$ & & \\
\hline
\end{tabular}

Araştırmaya katılan örneklem grubunun, psikolojik şiddet boyutları ile yaş değişkeni arasında istatistiksel bir farklılaşma olup olmadığı araştırılmış, 0,05 anlamlılık düzeyinde psikolojik şiddetin ortalama olarak $(F=1,433$ ve $p=0,222)$ ile yaş değişkeni arasında $(p<0,05)$ anlamlı bir farklılaşmanın olmadığı görülmüş̧ür. Buna göre $\mathrm{H}_{2.1}$ hipotezi yeterli kanıtla desteklenememiştir.

Araştırmaya katılan örneklem grubunun, iş doyum boyutları ile yaş değişkeni arasında istatistiksel bir farklılaşma olup olmadığ şiddetin ortalama olarak $(F=2,043 v e ~ p=0,087)$ ile yaş değişkeni arasında $(p<0,05)$ anlamlı bir farklılaşmanın olmadığı görülmüştür. Buna göre $\mathrm{H}_{2.2}$ hipotezi yeterli kanıtla desteklenememiştir. 
Tablo 4: Çalışanların İş Doyumlarının Yaş Değişkenine Göre Farklılaşması

\begin{tabular}{|c|c|c|c|c|c|c|}
\hline & Yaş & $\mathrm{n}$ & $\bar{x}$ & $\mathrm{~s}$ & $\mathbf{F}$ & $\mathbf{P}$ \\
\hline \multirow{6}{*}{$\begin{array}{l}\text { İş Doyumu } \\
\text { Ortalaması }\end{array}$} & $20-25$ & 93 & 3,2194 & 0,7684 & \multirow{6}{*}{2,043} & \multirow{6}{*}{0,087} \\
\hline & $26-30$ & 155 & 3,171 & 0,76292 & & \\
\hline & $31-35$ & 111 & 2,9604 & 0,79756 & & \\
\hline & $36-40$ & 62 & 2,9734 & 0,95031 & & \\
\hline & 41 ve üzeri & 94 & 3,0351 & 0,91422 & & \\
\hline & Total & 515 & 3,0857 & 0,82789 & & \\
\hline
\end{tabular}

Baş ve Ardıç (2002) Türkiye genelinde yaptıkları çalışmada genel olarak çalışanların yüksek iş doyumuna sahip olduklarını ancak ücret ve iş güvenliği söz konusu olduğunda iş doyum düzeyinin düştüğünü ortaya koymuşlardır.

Yetiş, Katkat ve Bakıcı (2008), Atatürk Üniversitesi çalışanların iş doyumlarının orta düzeyde olduğunu genç elemanlarının 30 yaş üstü elemanlara kıyasla daha düşük düzeyde iş doyumuna sahip olduğunu tespit etmişlerdir.

Tablo 5: Çalışanların Psikolojik Şiddete Maruz Kalma Algılarının Eğitim Düzeyine Göre Farklılaşması

\begin{tabular}{|c|c|c|c|c|c|c|}
\hline & Eğitim Düzeyi & $\mathbf{n}$ & $\bar{x}$ & s & $\mathbf{F}$ & p \\
\hline \multirow{6}{*}{$\begin{array}{l}\text { Psikolojik } \\
\text { Şiddet } \\
\text { Ortalaması }\end{array}$} & İlköğretim & 9 & 2,4272 & 1,00522 & \multirow{6}{*}{1,635} & \multirow{6}{*}{0,164} \\
\hline & Lise & 37 & 2,1159 & 0,64729 & & \\
\hline & Önlisans & 47 & 1,9678 & 0,77735 & & \\
\hline & Lisans & 286 & 2,1286 & 0,78567 & & \\
\hline & Lisansüstü & 136 & 2,2632 & 0,84963 & & \\
\hline & Total & 515 & 2,1538 & 0,79944 & & \\
\hline
\end{tabular}

Araştırmaya katılan örneklem grubunun, psikolojik şiddet boyutları ile eğitim düzeyi arasında istatistiksel bir farklılaşma olup olmadığ 1 araştırılmış, 0,05 anlamlılık düzeyinde psikolojik şiddetin ortalama olarak $(\mathrm{F}=1,635$ ve $\mathrm{p}=0,164)$ ile eğitim düzeyi arasında $(\mathrm{p}<0,05)$ anlamlı bir farklılaşmanın olmadığı görülmüştür. Buna göre $\mathrm{H}_{3.1}$ hipotezi yeterli kanıtla desteklenememiştir.

Tablo 6: Çalışanların İş Doyumlarının Eğitim Düzeyine Göre Farklılaşması

\begin{tabular}{|c|c|c|c|c|c|c|}
\hline & Yaş & $\mathbf{n}$ & $\bar{x}$ & $\mathrm{~s}$ & $\mathbf{F}$ & $\mathbf{P}$ \\
\hline \multirow{6}{*}{$\begin{array}{l}\text { İş Doyumu } \\
\text { Ortalaması }\end{array}$} & İlköğretim & 9 & 2,8722 & 1,23392 & \multirow{6}{*}{1,091} & \multirow{6}{*}{0,36} \\
\hline & Lise & 37 & 3,2622 & 0,80695 & & \\
\hline & Önlisans & 47 & 3,2383 & 0,81034 & & \\
\hline & Lisans & 286 & 3,0559 & 0,8117 & & \\
\hline & Lisansüstü & 136 & 3,0618 & 0,84198 & & \\
\hline & Total & 515 & 3,0857 & 0,82789 & & \\
\hline
\end{tabular}

Araştırmaya katılan örneklem grubunun, iş doyum boyutları ile eğitim düzeyleri arasında istatistiksel bir farklılaşma olup olmadığı araştırılmış, 0,05 anlamlılık düzeyinde psikolojik 
şiddetin ortalama olarak $(\mathrm{F}=1,091$ ve $\mathrm{p}=0,036)$ ile eğitim düzeyi arasında $(\mathrm{p}<0,05)$ anlamlı bir farklılaşmanın olmadığı görülmüştür. Buna göre $\mathrm{H}_{3.2}$ hipotezi yeterli kanıtla desteklenememiştir.

Karcıoğlu ve Akbaş (2010) eğitim seviyesi açısından psikolojik şiddete maruz kalma durumları ile iş tatminleri karşılaştırıldığında ise çalışanlarının eğitim seviyeleri ile psikolojik şiddete maruz kalma durumları arasında anlamlı bir farklılık görülmüştür. Doktora eğitim seviyesine sahip çalışanların yüksek lisans, üniversite, lisans ve lise mezunu çalışanlarına göre daha fazla psikolojik şiddete maruz kaldıkları bulgusu elde edilmiştir.

Çivildağ ve Sargın (2012) psikolojik danışmanların işyerinde psikolojik tacize maruz kalma bakımından yaş değişkenine göre anlamlı düzeyde bir farklılık göstermedikleri belirlenmiştir.

Tablo 7: Çalışanların Psikolojik Şiddete Maruz Kalma Algılarının Kıdem Süresine Göre Farklılaşması

\begin{tabular}{|c|c|c|c|c|c|c|}
\hline & Kıdem Süresi & $\mathbf{n}$ & $\bar{x}$ & $\mathrm{~S}$ & $\mathbf{F}$ & $\mathbf{P}$ \\
\hline \multirow{6}{*}{$\begin{array}{l}\text { Psikolojik } \\
\text { Şiddet } \\
\text { Ortalaması }\end{array}$} & $0-1$ y1l & 84 & 1,9876 & 0,74384 & \multirow{6}{*}{1,36} & \multirow{6}{*}{0,247} \\
\hline & $2-5$ yil & 184 & 2,151 & 0,7595 & & \\
\hline & 6-10 yıl & 99 & 2,2311 & 0,8623 & & \\
\hline & $11-15$ y1l & 52 & 2,1453 & 0,81077 & & \\
\hline & 16 yıl ve üzeri & 96 & 2,2294 & 0,84075 & & \\
\hline & Total & 515 & 2,1538 & 0,79944 & & \\
\hline
\end{tabular}

Araştırmaya katılan örneklem grubunun, psikolojik şiddet boyutları ile kıdem süresi arasında istatistiksel bir farklılaşma olup olmadığı araştırılmış, 0,05 anlamlılık düzeyinde psikolojik şiddetin ortalama olarak $(\mathrm{F}=1,36 \mathrm{ve} \mathrm{p}=0,247)$ ile kıdem süresi arasında $(\mathrm{p}<0,05)$ anlamlı bir farklılaşmanın olmadığı görülmüştür. Buna göre $\mathrm{H}_{4.1}$ hipotezi yeterli kanıtla desteklenememiştir.

\section{Tablo 8: Çalışanların İş Doyumlarının Kıdem Süresine Göre Farklılaşması}

\begin{tabular}{|c|c|c|c|c|c|c|}
\hline & Kidem & $\mathbf{n}$ & $\bar{x}$ & $\mathbf{s}$ & $\mathbf{F}$ & $\mathrm{p}$ \\
\hline \multirow{6}{*}{$\begin{array}{l}\text { İş Doyumu } \\
\text { Ortalaması }\end{array}$} & 0-1 y1l & 84 & 3,1744 & 0,81198 & \multirow{6}{*}{0,781} & \multirow{6}{*}{0,538} \\
\hline & $2-5$ yil & 184 & 3,0783 & 0,78607 & & \\
\hline & 6-10 yıl & 99 & 3,0227 & 0,8663 & & \\
\hline & 11-15 y1l & 52 & 3,2029 & 0,81442 & & \\
\hline & 16 yıl ve üzeri & 96 & 3,024 & 0,8884 & & \\
\hline & Total & 515 & 3,0857 & 0,82789 & & \\
\hline
\end{tabular}

Araştırmaya katılan örneklem grubunun, iş doyum boyutları ile kıdem süresi arasında istatistiksel bir farklılaşma olup olmadığı araştırılmış, 0,05 anlamlılık düzeyinde psikolojik şiddetin ortalama olarak $(F=0,781$ ve $p=0,538)$ ile eğitim düzeyi arasında $(p<0,05)$ anlamlı bir farklılaşmanın olmadığı görülmüştür. Buna göre $\mathrm{H}_{4.2}$ hipotezi yeterli kanıtla desteklenememiştir. 
Tablo 9: Çalışanların Psikolojik Şiddete Maruz Kalma Algılarının Cinsiyete Göre Farklılaşması

\begin{tabular}{ccccccc}
\hline & Cinsiyet & $\mathbf{n}$ & $\overline{\mathbf{x}}$ & $\mathbf{s}$ & $\mathbf{F}$ & $\mathbf{p}$ \\
\hline $\begin{array}{c}\text { Psikolojik Şiddet } \\
\text { Ortalamas1 }\end{array}$ & Kadın & 314 & 2,1876 & 0,80935 & 1,201 & 0,23 \\
\cline { 2 - 5 } & Erkek & 201 & 2,1009 & 0,78277 & & \\
\hline
\end{tabular}

Araştırmaya katılan örneklem grubunun, psikolojik şiddet boyutları ile cinsiyet arasında istatistiksel bir farklılaşma olup olmadığ 1 araştırılmış, 0,05 anlamlılık düzeyinde psikolojik şiddetin ortalama olarak $(\mathrm{F}=1,201$ ve $\mathrm{p}=0,23)$ ile cinsiyet arasında $(\mathrm{p}<0,05)$ anlamlı bir farklılaşmanın olmadığı görülmüştür. Buna göre $\mathrm{H}_{5.1}$ hipotezi yeterli kanıtla desteklenememiştir.

Karcıoğlu ve Akbaş (2010) çalışmalarında çalışanlara uygulanan psikolojik şiddete maruz kalma durumu ile çalışanların cinsiyetleri arasında anlamlı bir fark olduğu görülmüş, erkek çalışanlar ile kadın çalışanlar arasında da $\mathrm{p}=0,028$ değeri ile $\mathrm{p}<0.05$ önem seviyesinde anlamlı bir fark bulunmuştur.

Tablo 10: Çalışanların İş Doyumlarının Cinsiyete Göre Farklılaşması

\begin{tabular}{ccccccc}
\hline & Cinsiyet & $\mathbf{n}$ & $\overline{\mathbf{x}}$ & $\mathbf{s}$ & $\mathbf{F}$ & $\mathbf{P}$ \\
\hline İş Doyumu & Kadın & 314 & 3,0486 & 0,78559 & $-1,274$ & 0,203 \\
\cline { 2 - 6 } Ortalaması & Erkek & 201 & 3,1438 & 0,88887 & & \\
\hline
\end{tabular}

Araştırmaya katılan örneklem grubunun, iş doyum boyutları ile cinsiyet arasında istatistiksel bir farklılaşma olup olmadığı araştırılmış, 0,05 anlamlılık düzeyinde psikolojik şiddetin ortalama olarak $(\mathrm{F}=-1,274 \mathrm{ve} \mathrm{p}=0,203)$ ile cinsiyet arasında $(\mathrm{p}<0,05)$ anlamlı bir farklılaşmanın olmadığ1 görülmüştür. Buna göre $\mathrm{H} 5.2$ hipotezi yeterli kanıtla desteklenememiştir.

Özkan ve Çetin (2011) kadın ve erkek katılımcıların iş doyumu düzeylerinin birbirinden anlamlı olarak farklı olduğunu tespit etmişlerdir. Buna göre, kadın çalışanların $(X=3,2990)$, erkek çalışanların iş doyumu düzeylerinden $(X=2,9250)$ daha yüksek olduğu sonucuna varılmıştır.Kişiliğin uyumluluk boyutunda kadın ve erkekler arasında farklılaşma görülmektedir. Kadın çalışanların $(X=4,1462)$, erkek çalışanlardan $(X=3,9248)$ daha uyumlu oldukları saptanmıştır.

Karcıoğlu ve Akbaş (2010) çalışmalarında kadın ve erkek çalışanların iş tatmin düzeyleri arasında anlamlı bir farklılık görülmemiştir. Yaş demografik değişkeni açısından bakıldığında ise çalışanlarının yaşları ile psikolojik şiddete maruz kalma durumları ve iş tatminleri arasında anlamlı bir ilişki olmadığı görülmüştür

Çivildağ ve Sargın (2012) çalışmalarında çalışanların işyerinde psikolojik taciz alt boyutlarının cinsiyet değişkenine göre analizi sonucunda anlamlı düzeyde farklılık göstermediği belirlenmiştir. Başka bir ifadeyle; kadın çalışanların ve erkek psikolojik danışmanların işyerinde psikolojik şiddete maruz kalma bakımından aralarında anlamlı düzeyde bir farklılık olmadığı belirlenmiştir.

Araştırmaya katılan örneklem grubunun, psikolojik şiddet boyutları ile medeni durum arasında istatistiksel bir farklılaşma olup olmadığı araştırılmış, 0,05 anlamlılık düzeyinde psikolojik şiddetin ortalama olarak $(F=-0,131$ ve $p=0,896)$ ile cinsiyet arasında $(p<0,05)$ anlaml bir farklılaşmanın olmadığı görülmüştür. Buna göre $\mathrm{H}_{6.1}$ hipotezi yeterli kanıtla desteklenememiştir. 
Tablo 11: Çalışanların Psikolojik Şiddete Maruz Kalma Algılarının Medeni Duruma Göre Farklılaşması

\begin{tabular}{ccccccc}
\hline & Medeni Durum & $\mathbf{n}$ & $\overline{\mathbf{x}}$ & $\mathbf{s}$ & $\mathbf{F}$ & $\mathbf{p}$ \\
\cline { 2 - 6 } $\begin{array}{c}\text { Psikolojik } \\
\text { Şiddet }\end{array}$ & Evli & 254 & 2,1491 & 0,81681 & & \\
Ortalamas1 & Bekar & 261 & 2,1583 & 0,78371 & & \\
\hline
\end{tabular}

Karcıoğlu ve Akbaş (2010)çalışanlarının medeni durumları ile psikolojik şiddete maruz kalma ve iş tatminleri arsında da anlamlı bir ilişki olmadığı ve medeni durumun psikolojik şiddete maruz kalmayı ve iş tatminini etkilemediği bulgusu elde edilmiştir. Özkan ve Vural (2011) çalışmaları sonucunda katılımcıların medeni durumlarına göre anlamlı farklılıklar bulunmuştur.

Tablo 12: Çalışanların İş Doyumlarının Medeni Duruma Göre Farklılaşması

\begin{tabular}{clccccc}
\hline & Medeni Durum & $\mathbf{n}$ & $\overline{\mathbf{x}}$ & $\mathbf{s}$ & $\mathbf{F}$ & $\mathbf{p}$ \\
\hline \multirow{2}{*}{$\begin{array}{l}\text { İş Doyumu } \\
\text { Ortalamas1 }\end{array}$} & Evli & 254 & 3,0406 & 0,84541 & & \\
\cline { 2 - 7 } & Bekar & 261 & 3,1297 & 0,80968 & $-1,222$ & 0,222 \\
\hline
\end{tabular}

Araştırmaya katılan örneklem grubunun, iş doyum boyutları ile medeni, durum arasında istatistiksel bir farklılaşma olup olmadığ 1 araştırılmış, 0,05 anlamlılık düzeyinde psikolojik şiddetin ortalama olarak $(\mathrm{F}=--1,222 \mathrm{ve} p=0,222)$ ile cinsiyet arasinda $(\mathrm{p}<0,05)$ anlamlı bir farklılaşmanın olmadığı görülmüştür. Buna göre $\mathrm{H}_{6.2}$ hipotezi yeterli kanıtla desteklenememiştir.

Tablo 13: Çalışanların Psikolojik Şiddete Maruz Kalma Algılarının Çalışılan Kuruma Göre Farklılaşması

\begin{tabular}{ccccccc}
\hline & Kurum & $\mathbf{n}$ & $\overline{\mathbf{x}}$ & $\mathbf{s}$ & $\mathbf{F}$ & $\mathbf{p}$ \\
\hline $\begin{array}{c}\text { Psikolojik } \\
\text { Şiddet }\end{array}$ & Kamu & 141 & 2,268 & 0,85782 & & \\
\cline { 2 - 6 } Ortalaması & Özel & 374 & 2,1107 & 0,77311 & & \\
\hline
\end{tabular}

Araştırmaya katılan örneklem grubunun, psikolojik şiddet boyutları ile çalışılan kurum arasında istatistiksel bir farklılaşma olup olmadığı araştırılmış, 0,05 anlamlılık düzeyinde psikolojik şiddetin ortalama olarak $(F=-1,997$ ve $p=0,46)$ ile cinsiyet arasında $(p<0,05)$ anlamlı bir farklılaşmanın olmadığı görülmüştür. Buna göre $\mathrm{H}_{7.1}$ hipotezi yeterli kanıtla desteklenememiştir.

Çalışkan ve Tepeci (2008) cinsiyet değişkeni dikkate alındığında, örneklemdeki erkek ve bayanlar eşit oranlarda psikolojik şiddete maruz kalmışlardır. Kadınların erkeklere oranla daha fazla psikolojik şiddet davranışlarına maruz kaldığı çalışmalar olsa da (Björkqvist vd., 1994) bu literatürde yaygın olarak elde edilen bir sonuç olmamıştır (Einarsen, 2000).

Araştırmaya katılan örneklem grubunun, iş doyum boyutları ile çalışılan kurum arasında istatistiksel bir farklılaşma olup olmadığ 1 araştırılmış, 0,05 anlamlılık düzeyinde psikolojik şiddetin ortalama olarak $(\mathrm{F}=-0,804 \mathrm{ve} \mathrm{p}=0,422)$ ile çalışılan kurum $(\mathrm{p}<0,05)$ anlamlı bir 
farklılaşmanın olmadığ1 görülmüştür. Buna göre $\mathrm{H7.2}$ hipotezi yeterli kanıtla desteklenememiştir.

Tablo 14: Çalışanların İş Doyumlarının Çalışılan Kuruma Göre Farklılaşması

\begin{tabular}{ccccccc}
\hline & Kurum & $\mathbf{n}$ & $\overline{\mathbf{x}}$ & $\mathbf{s}$ & $\mathbf{F}$ & $\mathbf{p}$ \\
\hline \multirow{2}{*}{$\begin{array}{c}\text { İş Doyumu } \\
\text { Ortalamas1 }\end{array}$} & Kamu & 141 & 3,0379 & 0,79808 & \multirow{2}{*}{$-0,804$} & \multirow{2}{*}{$-0,422$} \\
\cline { 2 - 6 } & Özel & 274 & 3,1037 & 0,8392 & & \\
\hline
\end{tabular}

\begin{tabular}{|c|c|c|c|c|c|c|}
\hline \multicolumn{7}{|c|}{ Olmamasına Göre Farklılaşması } \\
\hline & Yöneticilik & $\mathbf{n}$ & $\bar{x}$ & $\mathrm{~s}$ & $\mathbf{F}$ & $\mathbf{p}$ \\
\hline Psikolojik & Evet var & 174 & 2,1554 & 0,84376 & \multirow[b]{2}{*}{0,034} & \multirow[b]{2}{*}{0,973} \\
\hline $\begin{array}{c}\text { Şiddet } \\
\text { Ortalamas1 }\end{array}$ & Hayur yok & 341 & 21529 & 077712 & & \\
\hline
\end{tabular}

Araştırmaya katılan örneklem grubunun, psikolojik şiddet boyutları ile çalışanın yönetici olup olmaması arasında istatistiksel bir farklılaşma olup olmadığ araştırılmış, 0,05 anlamlılık düzeyinde psikolojik şiddetin ortalama olarak $(\mathrm{F}=0,034 \mathrm{ve} \mathrm{p}=0,973)$ ile cinsiyet arasında $(\mathrm{p}<0,05)$ anlamlı bir farklılaşmanın olmadığı görülmüştür. Buna göre $\mathrm{H} 8.1$ hipotezi yeterli kanitla desteklenememiştir.

Tablo 16: Çalışanların İş Doyumlarının Yönetici Olup Olmamasına Göre Farklılaşması

\begin{tabular}{rcccccc}
\hline & Yöneticilik & $\mathbf{n}$ & $\overline{\mathbf{x}}$ & $\mathbf{s}$ & $\mathbf{F}$ & $\mathbf{p}$ \\
\hline \multirow{2}{*}{$\begin{array}{c}\text { İş Doyumu } \\
\text { Ortalaması }\end{array}$} & Evet var & 174 & 3,1966 & 0,8684 & \multirow{2}{*}{2,178} & \multirow{2}{*}{0,03} \\
\cline { 2 - 5 } & Hayır yok & 341 & 3,0292 & 0,80185 & & \\
\hline
\end{tabular}

Araştırmaya katılan örneklem grubunun, iş doyum boyutları ile çalışanın yönetici olup olmaması arasında istatistiksel bir farklılaşma olup olmadığı araştırılmış, 0,05 anlamlılık düzeyinde psikolojik şiddetin ortalama olarak ( $F=-2,178 v e ~ p=0,03)$ ile yönetici olup olmaması arasında $(\mathrm{p}<0,05)$ anlamlı bir farklılaşmanın olduğu görülmüştür. Buna göre H8.2 hipotezi yeterli kanitla desteklenmiştir.

Ortalamalara bakıldığında, yöneticilik vasfı bulunan çalışanların iş doyum oranı yöneticilik pozisyonunda olmayan çalışanlara oranla daha yüksek olmaktadır. Araştırma bulgularına göre yöneticilerin doyum düzeylerinin yönetici olmayanlara göre daha yüksek olduğu ortaya çıkmaktadır. Yöneticilik vasfı bulunmayan çalışanlara daha fazla imkanlar (ilerleme ve gelişme, terfi, kararlara katılma beklentileri gerçekleştirebilme, emsallerine göre ücret vb.) sağlanarak iş memnuniyetsizliğinin giderilmesi sağlanabilir.

\section{SONUÇ}

Psikolojik şiddet olgusu ister özel sektör olsun,ister kamu kurumları olsun, yaş, cinsiyet, eğitim vb. etkenler fark etmeksizin çalışma hayatının birçok alanında karşımıza çıkmaktadır. 
Dolayısıyla şiddetine göre de yıpratıcı etki bırakarak çalışanları iş ve meslek yaşamında oldukça zor durumda bırakmaktadır. Psikolojik şiddete karşı önlem alınmasına yönelik gerekli çalışmalar yapılmadığı takdirde kurumlarda en alt tabakadan en üst tabakaya kadar bir hızla yayılacak ve çalışana sadece bireysel olarak zarar vermekten çıkıp örgütün de büyük bir zarar görmesine neden olacaktır.

Araştırma sonuçlarında araştırmanın problemini destekleyici sonuçlar elde edilmiştir. Bununla birlikte araştırmada yapılan analiz ve testlerden elde edilen sonuçlar aşağıdaki gibidir:

1- Çalışanların psikolojik şiddet algısı ile iş doyumları arasındaki anlamlılığın yüksek olduğu tespit edilmiştir. Psikolojik şiddet algısı arttıkça iş doyumu düzeyinin düştüğü denilebilir. Buna göre $\mathrm{H}_{1}$ hipotezi yeterli kanıtla desteklenmektedir.

2- Çalışanların psikolojik şiddet algısı ile yaş değişkeni arasında istatistiksel olarak anlamlı bir ilişki olmadığı tespit edilmiştir. Dolayısıyla $\mathrm{H}_{2.1}$ hipotezi yeterli kanıtla desteklenememiştir.

3- Çalışanların iş doyum durumları ile yaş değişkeni arasında istatistiksel olarak anlamlı bir ilişki olmadığ tespit edilmiştir. $\mathrm{H}_{2} .2$ hipotezi yeterli kanıtla desteklenememiştir.

4- Çalışanların psikolojik şiddet algısı ile eğitim düzeyi arasında anlamlı bir ilişki olup olmadığı araştırılmış, analiz sonucunda istatistiksel olarak anlamlı bir ilişki olmadığı tespit edilmiştir. Dolayısıyla $\mathrm{H} 3.1$ hipotezi yeterli kanıtla desteklenememiştir.

5- Çalışanların iş doyum durumları ile eğitim düzeyi arasında anlamlı bir ilişki olup olmadığı araştırılmış, analiz sonucunda istatistiksel olarak anlamlı bir ilişki olmadığı tespit edilmiştir. $\mathrm{H} 3.2$ hipotezi yeterli kanıtla desteklenememiştir.

6- Çalışanların psikolojik şiddet algısı ile kıdem süresi arasında anlamlı bir ilişki olup olmadığı araştırılmış, analiz sonucunda istatistiksel olarak anlamlı bir ilişki olmadığ tespit edilmiştir. Dolayısıyla H4.1 hipotezi yeterli kanıtla desteklenememiştir.

7- Araştırmada iş doyum durumları ile kıdem süresi arasında anlamlı bir ilişki olup olmadığı araştırılmış, analiz sonucunda istatistiksel olarak anlamlı bir ilişki olmadığı tespit edilmiştir. $\mathrm{H}_{4.2}$ hipotezi yeterli kanıtla desteklenememiştir.

8- Araştırmada psikolojik şiddet algısı ile cinsiyet değişkeni arasında anlamlı bir ilişki olup olmadığı araştırılmış, analiz sonucunda istatistiksel olarak anlamlı bir ilişki olmadığı tespit edilmiştir. Dolayısıyla H5.1 hipotezi yeterli kanıtla desteklenememiştir.

9- Araştırmada iş doyum durumları ile cinsiyet değişkeni arasında anlamlı bir ilişki olup olmadığı araştırılmış, analiz sonucunda istatistiksel olarak anlamlı bir ilişki olmadığı tespit edilmiştir. H5.2 hipotezi yeterli kanıtla desteklenememiştir.

10- Araştırmada psikolojik şiddet algısı ile medeni durum arasında anlamlı bir ilişki olup olmadığı araştırılmış, analiz sonucunda istatistiksel olarak anlamlı bir ilişki olmadığı tespit edilmiştir. Dolayısıyla H6.1 hipotezi yeterli kanıtla desteklenememiştir.

11- Araştırmada iş doyum durumları ile medeni durum arasında anlamlı bir ilişki olup olmadığ tespit edilmiştir. H6.2 hipotezi yeterli kanitla desteklenememiştir.

12- Araştırmada psikolojik şiddet algısı ile çalışılan kurum arasında anlamlı bir ilişki olup olmadığı araştırılmış, analiz sonucunda istatistiksel olarak anlamlı bir ilişki olmadığı tespit edilmiştir. Dolayısıyla H7.1 hipotezi yeterli kanıtla desteklenememiştir.

13- Araştırmada iş doyum durumları ile çalışılan kurum arasında anlamlı bir ilişki olup olmadığı araştırılmış, analiz sonucunda istatistiksel olarak anlamlı bir ilişki olmadığ tespit edilmiştir. H7.2 hipotezi yeterli kanıtla desteklenememiştir.

14- Araştırmada psikolojik şiddet algısı ile çalışanın yönetici olup olmaması arasında anlamlı bir ilişki olup olmadığı araştıılmış, analiz sonucunda istatistiksel olarak anlamlı bir ilişki olmadığı tespit edilmiştir. Dolayısıyla H8.1 hipotezi yeterli kanıtla desteklenememiştir. 
15- Araştırmada iş doyum durumları ile çalışanın yönetici olup olmaması arasında anlamlı bir ilişki olup olmadığı araştırılmış, analiz sonucunda istatistiksel olarak anlamlı bir ilişki olduğu tespit edilmiştir. H8.2 hipotezi yeterli kanıtla desteklenmiştir. Araştırmaya katılan çalışanlar arasında yöneticilik vasfı bulunanların iş doyum düzeyleri ortalama olarak yöneticilik vasfı bulunmayanlardan daha yüksek olduğu denilebilir.

\section{ÖNERİLER}

1- Araştırmada anket yöntemine başvurulmuştur. İleride yapılacak olan araştırmalarda gönüllü çalışanlar ile yüz yüze görüşmeler yapılarak daha derin sonuçlar elde edilebilir.

2- Çalışanların ölçekleri yanıtlarken kişilik ve iş ile ilgili soruların cevaplarının sosyal beğenilirlik faktöründen etkilenebilecekleri düşünülerek anketin internet üzerinden uygulanabilir versiyonu hazırlanmıştır. Katılımcıların, bu şekilde daha dürüst ve samimi yanıtlar verecekleri düşünülmüştür ancak bu şekilde de katılımcıların takip edilmesi güçleşmiştir.

3- Psikolojik şiddetin varlığı mağdurların davranışı nasıl algıladıkları ile de ilgili olmaktadır. Kişilerin davranışları nasıl algıladıkları ve bilincine varmaları kültürleri ile ilgilidir dolayısıyla yapılacak olan çalışmalarda örneklem grubunun kültürel özelliklerinin dikkate alınması daha geçerli sonuçlara ulaşmayı sağlayabilir.

4- Araştırmada genel iş doyum düzeyini ölçen bir ölçek kullanılmıştır. İş doyumu kişisel, örgütsel ve çevresel faktörlerden etkilenebileceğinden dolayı elde edilen çalışanların iş doyum sonuçlarının tam olarak doğrudan psikolojik şiddete maruz kalmaya dair sonuçlar olduğu söylenemez. Dolayısıyla alt iş doyumu ve psikolojik şiddetin alt boyutlarının (ücret, yönetim gibi) derin ve ayrıntılı olarak incelenmesi uygun olabilir.

\section{KAYNAKÇA}

Acar, E. (2007). Uzmanlık Alanında Çalışmanın İş Doyumuna Etkisi, Paradoks, Ekonomi, Sosyoloji ve Politika Dergisi, (e-dergi), 3(2) http://www.paradoks.org, (Erişim Tarihi: 21.06.2017).

Akıncı, Z. (2002). Turizm Sektöründe İşgören İş Tatminini Etkileyen Faktörler: Beş Yıldızlı Konaklama İşletmelerinde Bir Uygulama, Akdeniz İ.I.B.F. Dergisi, (4), 1-25.

Barutçugil, İ. S. (1992). İşletmelerde Yöneticilerin Eğitimi ve Geliştirilmesi, Uludă̆ Ünv. İktisat ve Sosyal Bilimler Dergisi, Cilt:3 Sayı:1 Temmuz.

Einarsen S., (1999). The Nature and Causes of Bullying at Work, International Journal of Manpower, Vol.20, Nos. 1-2.

Ellis, S. and Dick, P. (2003). Introduction to Organizational Behaviour. London: McGraw-Hill

Gün, H (2010). Çalışma Ortamında Psikolojik Taciz. (2. Baskı), Ankara: Lazer Yayıncilik.

Kalleberg, Arne L. and Karyn A. Loscocco (1983). Aging, Values and Rewards: Explaining Age Differences in Job Satisfaction, American Sociological Review, 48(1):7890. 
Leymann, H. (1996). The Content and Development of Mobbing at Work, European Journal of Work and Organizational Psychology, 5, s.165-184.

Sabuncuoğlu, Z. (1997). Personel Yönetimi, Politika ve Yönetsel Teknikler, 8. Baskı, Bursa: Ezgi Kitabevi.

Sabuncuoğlu, Z. ve Tuncer T. (2001). İşletme, Bursa: Ezgi Kitabevi.

Sarabahksh M, David C. and Elaine L. (1989). Hospitality Managers' Stres and Quality of Life: Recommendation for Change", Journal of Hospitality \& Tourism Research, 13(3): 239-245.

Şimşek Ş, Çelik A. ve Akgemci T. (2016). Davranış Bilimlerine Giriş ve Örgütlerde Davranış, Eğitim Yayınevi, Konya. 